\title{
THE TAX COMPLIANCE RISK FOR BANK PAYMENT TRANSACTIONS IN THE TAX ADMINISTRATION CONTEXT IN VIETNAM
}

\author{
Võ Tiến Dũng \\ Business Administration Faculty, HUTECH-Vietnam, votiendung71@gmail.com
}

\begin{abstract}
The article provides the reference on tax compliance risk for bank transactions payments by businesses in the context of developing countries such as Vietnam, as tax departments are gradually modernizing the tax administration. The methods used in this study are: Analyzing the data from references in order to evaluate the relationship between abnormal signs in bank transactions and the amount the taxpayer has to pay, Experimenting in each chosen case (individually tax auditing), Interviewing closely with tax auditing experts, Releasing the first version of tax auditing result in comparison with the abnormal signs to discover potential risks, Discussing with domestics experts in the field, Reviewing and releasing the second draft, Evaluating the documents established by independent experts from Vietnam Tax Department, and Officially publishing the studies in the Vietnam tax field. The review of the materials examines the issues involved in the field of tax compliance risk management and to identify gaps in the study of a tax compliance risk. The result of this study shows that there are potential tax compliance risks for companies' bank transactions in tax administration context in Vietnam since 2014. This is a gap in tax compliance studies. The difference between this study and other tax compliance studies is being able to identify the tax compliance risk for bank payment transactions. The outcome of this study is not only valuable for science but also highly applicable for tax administration department.
\end{abstract}

\begin{abstract}
Abstrak
Artikel ini bertujuan untuk membahas tax compliance risk untuk transaksi pembayarn di bank oleh perusahaan dalam konteks Negara berkembang seperti Vietnam, dimana departemen pajaknya secara bertahap memoderinisasi administrasi perpajakan. Metode yang digunakan dalam penelitian ini: menganalisis data dari referensi dalam rangka mengevaluasi hubungan antara transaksi bank dan jumlah yang dibayar oleh wajib pajak, melakukan eksperimen pada setiap kasus terpilih (tax auditing secara individual), melakukan interview dengan ahli tax auditing, melaporkan versi awal hasil tax auditing sebagai hasil pembandingan dengan tandatanda abnormal yangn menunjukkan risiko potensial, mendiskusikannya dengan ahli-ahli domestic dalam bidangnya, melakukan review dan melaporkan draft kedua, mengevaluasi dokumen yangn ditetapkan oleh ahli independen dari departemen pajak Vietnam, dan secara resmi mempublikasikan hasil penelitian ini. Penelaahan materi untuk menentukan isu-isu yang terkait dengan tax compliance risk management dan untuk mengidentifikasi gaps dalam bidang tax compliance risk. Hasil penelitian ini menunjukkan bahwa terdapat potential tax compliance risks untuk transaksi bank yangn dilakukan perusahaan dalam konteks administrasi perpajakan sejak tahun 2014. Hasil ini mennunjukkan adanya gap tentang tax compliance. Perbedaan antara penelitian ini dengan penelitian sebelumnya adalah dapat mengindentifikasi tax compliance risk untuk transksi pembayaran di bank. Outcome dari penelitian ini tidak hanya bermanfaat untuk ilmu pengetahuan, tetapi juga dapat diterapkan di departemen perpajakan.
\end{abstract}

Keywords: risk, tax auditing, tax compliance 
JEL Classification: E62, G32

\section{Research Background}

The previous empirical study results have demonstrated that taxpayers' compliance or non-compliance will be influenced by a variety of elements depending on the context of each country. Most studies on tax compliance management emphasize the duty of tax department improve the level of taxpayer compliance through a process of understanding the factors that affect tax compliance, which is especially important to apply self-tax returns. Studies have also shown that the higher the probability of identifying fraudulent behaviors and fraudulent capacity of tax department, the higher the tax compliance. However, according to the OECD (2004), all tax departments have limited resources to ensure that all taxpayers comply with tax liability. This requires the most reasonable method of allocating their resources, which is not simple at all. What are the main risks? What are the risks associated with taxpayers? How to solve these risks to achieve the best results? The answer to these questions is complicated by the variety of taxpayers' compliance behavior and the factors underlie that behavior. Therefore, requires the tax department to have a structured and systematic process to define what is important in a tax compliance context and how the main compliance risks will be solved. The compliance risk management process is designed to assist tax department to answer these questions comprehensively. Organization for Economic Co-operation and Development (OECD 2004) and Customs Union - European Commission (EC 2006) has developed a compliance risk management model as well as a number of criteria to identify the most common risk to guide tax department. However, these organizations also make the following recommendations: compliance risk management model could not be completely correct in all contexts of tax administration; it should not be applied rigidly, but it should be understood that this is only a general guideline for managing compliance risk. In short, it should be applied in a way that is appropriate to each specific situation based on this general guideline. Guidance on Compliance Risk Management (OECD 2004) through long-term research since 1997 and comments from many OECD member countries (including Australia, Austria, Canada, Denmark, Finland, France, Germany, Greece, Ireland, Japan, Korea, New Zealand, Norway, Sweden, Switzerland, United Kingdom, including the Internal Revenue Service and Customs - USA) emphasizes that each tax administration has different operating environments: tax system, tax policy, legal environment, administrative affairs and culture. Thus, a common standard approach to all management may not be practical and OECD (2004) does not present a specific case. The document should be carefully and thoroughly explained with the above considerations when considering a country's actual situation. There will be common risks and identifications, but there will also be risks and specific identification of specific tax administration contexts in each country. These are gaps researchers as well as the tax administration to take into consideration in order to add to the context. Vietnam Internal Tax Administration has formally approached the application of risk management since 2010 in the tax audit, throughout the process of implementation and addition, set of risk assessment criteria for tax inspection and examination has basically been completed. This set of criteria focuses on the vertical and horizontal analysis of the tax records in the database of tax department such as: tax returns, financial reports to be submitted, taxation, history of compliance, and information from the third parties (banks, police, customs) to identify risks. In the context of Vietnam's tax administration, a great risk which is not mentioned in this set of criteria is the tax risk for bank payment transactions. If these transactions are untrue, then the resulting taxpayers' information disclosure may be dishonest. Currently, relevant studies and practices assessing tax compliance risks in Vietnam are still at an early stage and have not yet developed a database of signs of tax fraud. Based on the review of the literature that will be presented in the following sections, we find that there is a gap in the tax compliance risk study for bank payment transactions. Therefore, the study of 
the tax compliance risk for bank payment transactions is necessary for academic as well as for tax administration in the context of specific tax administration in Vietnam.

\subsection{Tax compliance}

There are a lot of studies on this subject in different perspective, and the concept of tax compliance is also inconsistent. For example, Allingham and Sandmo (1972) in study of adherence to income tax, assumed that tax compliance was a matter of reporting actual earnings, and identified taxpayer decisions in the uncertainty of the outcome of these actions. Therefore, Allingham and Sandmo (1972) argue that most taxpayers are involuntarily compliance with tax; they choose compliance or non-compliance based on the probability of being detected and the punishment if detected, Clotfelter (1983) has same point of view. Meanwhile, Song and Yarbrough (1978) when accessing the US tax system find that the tax system operates on the basis of a capable and willingness of taxpayers to self-assess their tax obligation and pay statutory taxes, this requires a high degree of voluntary compliance with tax law of taxpayers, and thus compliance is the result of the regulatory environment, ethics, and other factors in each situation of space and time. In another study, Jackson and Milliron (1986), Alm (1991) argue that tax compliance strictly complied with the provisions of tax law on receivables must report and make payments on time. More than five years later, Andreoni et al. (1998) emphasized the willingness of taxpayers to fulfill their obligations and they suggested tax compliance should be interpreted as a willingness to follow the provisions of the tax law. The simplest of these is that of James and Alley (2004), whereby tax compliance is the degree to which taxpayers meet the obligations set out in the tax laws or in the Kirchler (2007) concept, tax compliance is a term used to refer to taxpayers' willingness to pay taxes. Singh (2003a) with a detailed study of taxpayers' fulfillment obligations, argues that tax compliance must be regarded as a deliberate and sufficient compliance with tax laws that are not affected by any tax law from the tax department in submitting tax returns, disclosing information related to the determination of tax obligations and tax payment. OECD (2004) studies, in a tax administration perspective, have introduced the concept of tax compliance as meeting the obligations of taxpayers in accordance with law, although the exact obligations of the taxpayers are different but basically the obligations that taxpayers include: enroll in the system (tax registration), file or provide information related to the timely determination of tax obligations, complete and accurate information reporting (in combination with good documentation), payment of obligations on time. Committed with the notion of compliance, the OECD countries include Australia, Austria, Canada, Denmark, Finland, France, Germany, Greece, Ireland, Japan, Korea, New Zealand, Norway, Sweden, Switzerland, the United Kingdom, and the United States have applied the practice of tax administration in their country. The European Commission introduced a theoretical framework as well as practical experience in more than 20 countries in the field of risk management in tax administration (EC, 2006) and compliance risk management In Tax Administration (EC 2006), it is also based on the OECD's understanding of compliance and non-compliance.

Through analyzing the given documents, there are many different concepts about tax compliance based on the context of each researcher. In the situation when there are diverse concepts to the issue, choosing the suitable concept will result in accurate researching result. Approaches the theory of tax compliance to the tax administration practices presented in documents of tax administration in OECD countries (2004), European Union Customs and Tariff Union (EC 2006), as a tax inspector who is currently working in the Vietnam Tax Department system, the writer choose the tax compliance concept of OECD (2004) for this study, also because of its suitability for the Vietnam tax administration context. According to the chosen document, the tax compliance concept towards businesses is founded on obeying exactly all the regulations, as stated in the law: (1) Registering in the system (of tax 
compliance): Submitting all the necessary documents to the tax department before the deadline as stated in the law before the time the company starting their business in order to begin the tax declaration and the process of update the file when there are any changes that needs to be reported to the tax department, as stated in the law (For example: Changes in funding, director, accountant, business system). (2) Submitting all the compulsory tax reports on time, as stated in the law. (3) Determining the required tax amount accurately, giving and storing enough information and related documents to the tax amount, as stated in the law. And (4) Submitting all the required tax types on time, as stated in the law.

2.

\section{Research Design}

According to Vietnam's tax law, transactions of goods and services purchased in the country (export of goods, services or imports of goods and services are not subject to our study) if the transaction value from 20.000.000 VND (including VAT), the payment should be payment by bank transfer. Enterprises are only allowed to declare the costs of invoicing and payment through banks. In fact, there are businesses that provide invoices that do not come with the supply of goods or services used by other businesses for tax evasion, otherwise, businesses that provide invoices will receive a certain amount of money under the agreement. This means there are companies intentionally do not comply with the tax by declaring fictitious charges or statements higher than actual costs, and they need documentation to prove these frauds, they will pay for businesses which willing to provide invoices without attaching goods or services. The problem is how to prove that a sum has been transferred from the buyer to the seller even though no goods or services are traded. Therefore, the parties have made one or more transactions through banks to prove this payment.

Data on tax returns and financial statements of taxpayers only provide aggregate data for a wide range of transactions and business activities of a business period in accordance with tax laws. The tax authorities use these data to perform analyzes to detect tax compliance risks. However, these data can not be detailed as each specific transaction, so it is not possible to find how many transactions have a taxable risk sign in the aggregate data. The tax authorities of Vietnam and the State Bank of Vietnam have agreed on the exchange of information in the course of operation to serve the work of each party. However, the exchange of information is mainly carried out in a number of specific cases and the information recorded on the information storage instrument is largely paper documents. The parties do not have a common database on enterprises, are not allowed to proactively exploit each other information on the database system. Therefore, the tax authorities can not detect the transaction through the bank has unusual signs without information from the bank.

When inspecting the tax at some enterprises have found the recording of costs have invoices, documents proving the expense was paid by transfer from the seller's bank account to the buyer. However, by examining these transactions, there are abnormal signs when the money transfer and withdrawal transactions on the two accounts of the seller and the buyer are executed by one person, at the same time and on the same bank. Through the implementation of measures in the tax inspection, taxpayers have admitted to have established artificial cash flow to prove the fake expense. This lead to lost tax due to the act of deliberately not complying with the obligation to report accurately the tax payable.

The issues mentioned above have shown that the risk of compliance with tax for banking transactions is real. Based on the research literature, we find that there is no specific case study on the tax compliance risk for bank transfer transactions in the context of developing countries such as Vietnam and tax department is gradually being modernized, data base as well as the sharing and use of related data between tax authorities and banks are not favorable. 
Tax compliance risk

Risk management guideline "Risk management guide for tax administrations" (EC 2006) and risk management compliance guideline "Compliance risk management guide for tax administrations" in tax administration in 2006 defined risk is "Negative things could affect the organization's ability to achieve its goals" (EC 2006) and the risk is "threats or probabilities that an action or event will affect bad for an organization's ability to achieve its goals "(EC 2006). Thus, "if the result is a higher level of compliance then the risk of compliance could also be interpreted as an opportunity of non-compliance." "Risks are facts or circumstances that may cause problems for organizations" (EC 2006). According to the EC (2006), the risks will vary widely depending on the objective, both external and internal risks must be identified as the behavior of taxpayers (external risk) and corrupt practices of tax officers (internal risk).

The EC's perspective of compliance risk both covers the commonality of risk and specificities in the tax field. We agree with this view, although argue that the risk of tax compliance in the context of our research is a risk of negative impacts on the state budget revenue, which tax department face in the event of taxpayers fail to meet the statutory obligations in the registration, declaration and payment of taxes. Simpler, the risk of compliance is incompliance.

\subsection{Incompliance}

Young (1994) identified 64 elements relating to incompliance of taxpayers or company when considering incompliance of Michigan, US tax amnesty program. Cuccia (1994) argues that incompliance is an illegal tax evasion, unlike tax evasion. The other explanation for incompliance is failure of taxpayers to make the filing of a required tax return, report accurately the tax obligation, and determine tax laws, or a tax in term, due to declining incomes or overreporting expenses (Singh 2003b). Inheriting the research results and contributions of member countries, the OECD (2004) formally instructs, if the taxpayer fails to meet any obligation to register, submit or provide Information relating to the determination of tax obligations, the reporting of information (in combination with the filing of documents), payment of tax obligations, they may be considered incompliant. The OECD (2004) argues that taxpayers' actions, whether due to ignorance, carelessness, recklessness or deliberate, as well as acts of taking advantage tax administration weaknesses that affects the performance of tax obligations is a case of non-observance of tax law, these are inevitable. Incompliance with taxation is difficult to measure as it involves the concealment of the actual level of revenues of individuals and companies whether intentionally or unintentionally. There are a lot of studies on factors related to incompliance of taxpayers. For example, Tax examine probability: in the Allingham and Sandmo (1972) tax evasion model the probability of being detected is one of the variables that affect tax evasion, if this probability is low (according to the subjective judgment of the person taxpayers) will encourage taxpayers to decide not to comply. Incompliant behavior of taxpayers is mainly detected through tax audits, and an increase in audit rates may lead to increased income in the taxpayer's report (Clotfelter 1983; Dublin and Wilde 1988; Beck et al. 1991) has same perspective. Massimo (1993) points out the reason taxpayers do not fully escape tax liability is the high probability of being detected. In fact, a tax examine is considered to be both a direct preventive measure for taxpayers examined and indirect effects on taxpayers who have not been examined (Alm 1993). Perception of risk detected through tax examine have important implications for taxpayers' incompliance, an increasing in the actual examine rate combined with the widespread disclosure of tax examines will have significant implications for taxpayers' awareness resulting in a reduction in incompliance (Carnes and Englebrecht 1995). On the other hand, the detection rate reduction of tax examine, incompliance will increase (White et al. 1993; Lederman 2003). Tax: Allingham and Sandmo (1972), who pioneer in tax compliance research, argue that tax rates do not make a significant 
contribution to tax evasion, they use a statistical model to understand the relationship between real income the tax rate, the penalty, the probability of the tax evasion, and in conclusion that taxpayers may choose to report incomes below the actual amount incurred without regard to tax rates. Porcano (1988) has the same perspective argue that tax rates do not affect incompliance. However, most studies support the idea that high tax rates will increase incompliance with taxes (Spicer and Becker 1980; Milliro and Toy 1988; Christian and Gupta 1992; Joulfanian and Rider 1998; Sour 2001). Clotfelter (1983) asserts that there is a positive correlation between taxation and tax evasion. Feinstein (1991) finds that there is a clear relationship between tax rates with compliance or incompliance in tax returns, most taxpayers are taxsensitive and they will react to small effects of changes in the tax bracket (Christian and Gupta 1992). It is important that the reporting of taxpayers' deficits may be proportional to the tax rate (Joulfanian and Rider 1998). Increasing marginal tax rates may be one of the motivating factors for taxpayers to decide on tax evasion (Witte and Woodbury 1985; Torgler, 2007), the contrast is uncertainty when lower tax rates increase. (Trivedi et al. 2004; Kirchler 2007). Complex tax system: Clotfelter's (1983) study of the complexity of the tax system involved in indeclare, Jackson and Milliron (1986), also found that one of the reasons for incompliance was the complexity of the tax system. The complexity consists of two aspects: tax laws are issued with too much detail or too much calculation. The complexity affects incompliance by misleading rules, omissions, and accidental errors to deliberately report below the actual level (Gupta 2002), this may lead to a decrease in taxpayers' perceptions of the tax system's impartiality and subsequently increase incompliance (Beck et al. 1991). In the OECD project (2001) on issues that adversely affect the performance of tax obligations, if the tax law is inaccurate and unclear, taxpayers will try to avoid taxation. In the context of low compliance in developing countries, the complexity of the tax system such as multiple income tax deductions, countless incentives, too many targets, will negatively affect the attitudes of taxpayers, attitudes that affect intentions and intentions to affect behavior (Richard 2015). In addition, tax evasion is more common in small businesses (sole proprietors) than large ones in many countries (Schuetze 2002). However, Adam and Sheffrin (2002) in another view suggest that tax complexity may not necessarily be considered unfair, and simplifying the tax system could not effectively prevent incompliance. The tax system fairness perception: equity is a priority concern of taxpayers. Equity is an objective requirement in the tax development process. Taxpayers are more aggressive declare when the tax system ensures equity in the mobilization of tax obligations. Managers and taxpayers believe that dissatisfaction with the fairness of the tax system is a major of incompliance. Spicer and Becker (1980) found that the behavior of taxpayers' incompliance significant increased when they awareness they were victims of unfair tax obligations. The spirit of taxpayers increases as they receive respect, taxpayers tend to avoid taxation if tax officials rely solely on deterrence (Frey and Feld 2002). Improving the quality of public services is one of the solutions that will improve the perception of fairness in the tax system (Roberts 1994), and an increase in awareness of equity may also help to reduce incompliance (Forest \& Sheffrin 2002).

The factors that affect tax compliance found in the studies was useful for the tax department to have appropriate strategies to address the underlying causes of incompliance. The issue is highlighted in most studies as in the guidelines on compliance management, tax compliance management by organizations such as OECD (2004), EC (2006), ATO (2009). However, studies on taxpayers' compliance or incompliance are not intended to specifically identify a case of incompliance as: enroll in the system (tax registration), provide information related to the timely determination of tax obligations, complete and accurate information reporting (in combination with good documentation), payment of obligations.

\subsection{Regulatory tax compliance}




\subsubsection{International studies}

"Regulatory Compliance Management: Governance and the Advancement of Tax Compliance" by the Organization for Economic Co-operation and Development (OECD, 2004) approach to specific regulatory processes in the tax area. The OECD (2004) identifies and discusses common principles found to include the identification of appropriate methods to address risks in a wide range of jurisdiction, provides an insight into the ways in which riskmanagement strategies affect behavior related to taxpayers' tax liability. According to the OECD (2004), taxpayers' actions, whether by ignorance, carelessness, recklessness or deliberate shirking taxes, which affect the performance of tax obligations are cases of nonobservance of tax law and these are unavoidable issues, thus compliance management to ensure that incompliance tax law is kept to a minimum. From the writer's point of view, even intentionally or not, if the taxpayer does not obey the tax obligations, it will cause damage to the tax compliance process. The difference is only in determining the level of punishment the taxpayer has to receive (intentional case gets higher punishment than unintentional one). In the context where the number of taxpayer, the growth of e-business and the establishment of new business method is continuously on the rise, tax department with limited human resources will be unable to ensure that all taxpayers obey their obligations. Therefore, applying risk management in tax compliance administration is crucial in order to minimize all the risks. However, according to the OECD (2004) analysis, there are clearly different levels of incompliance. How to arrange hierarchical compliance risks? How to make a decision to ignore or take immediate action for a incompliant behavior? For example, the behavior of incompliance due to accidental or deliberate error will have different behaviors. For these issues, tax administration requires a structured and systematic process to determine what is important and how critical compliance risks will be resolved in one specific tax administration context. The OECD (2004) has identified a framework for compliance risk management that can be applied to tax administrations:

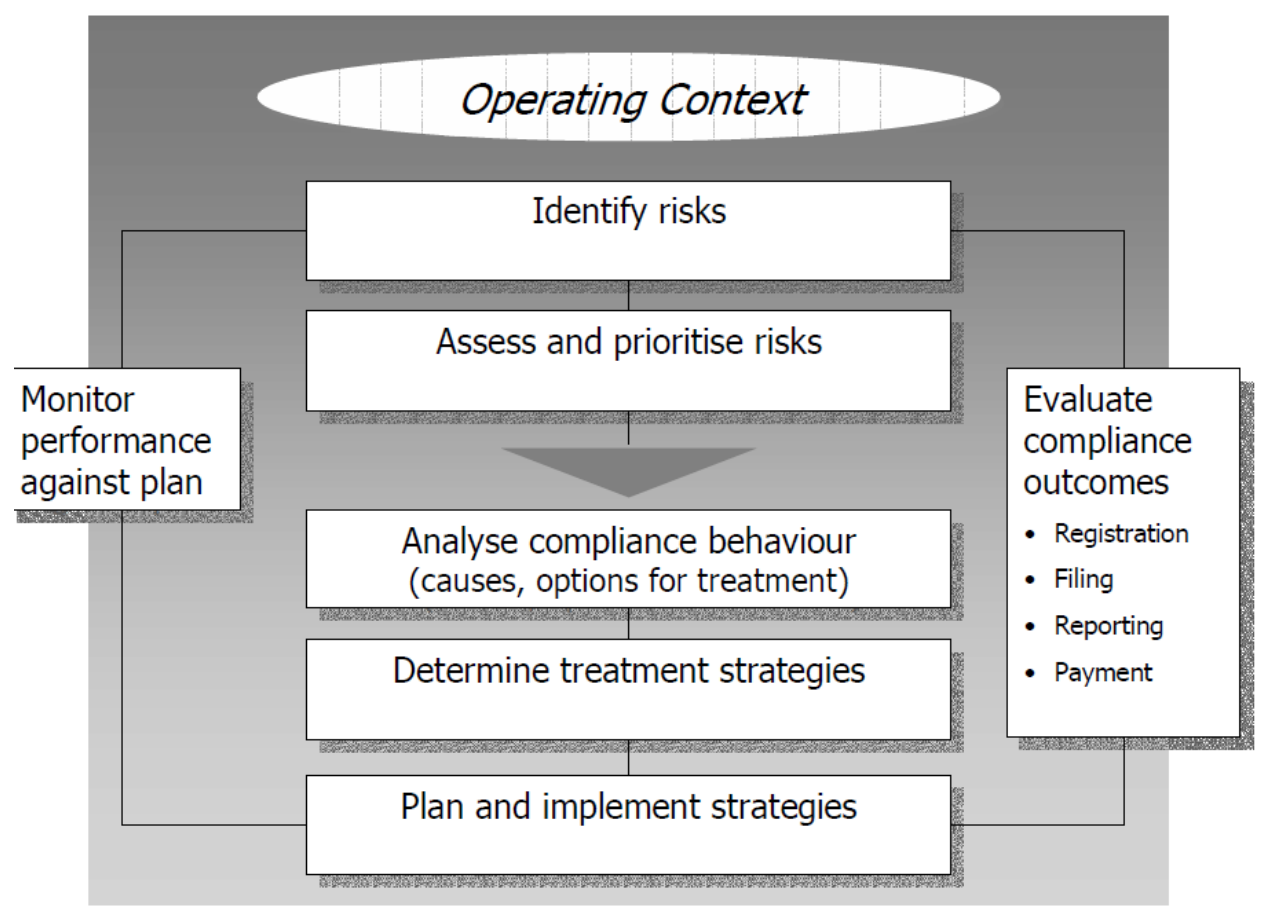

Figure 1. The Compliance Risk Management Process

Source: OECD (2004)

The OECD (2004) formally describes "Compliance risk management is a structured process in identifying a system for assessing, rating, and addressing compliance risks. (For example: not 
registering tax, reporting incorrect bases related to the determination of payable tax ...)". As risk management in general, it is an iterative process that has been defined to assist in improving decision making. "Compliance risk management looks at risks that affect compliance with tax registration, filing, tax reporting or taxation obligations" (OECD 2004). The OECD (2004) provides a specific guide to how to apply the most common compliance risk framework, and emphasizes the appropriate application tax compliance in the context of specific country. Compliance risk management can be applied at the strategic level (from the top down as macroeconomic analysis technique) or at the tactical / operational level (bottom-up as the risk based risk enumerator according to the situation) or boths. Risks identified at the strategic level often require broad knowledge and interventions by management that should be very careful as it will affect the entire taxpayers, not just the places at risk. While the risk at the operational level can often be treated as repeated work. Most tax administrations use a variety of data sources and techniques to manipulate data, analysis tools, indicators to identify risks and assess its importance. The methods recommended by the OECD (2004) in the risk management process include: Customer Segmentation: which is a term borrowed from Marketing to help an organization better understand its customers; Trend analysis through the macro indicators, the public opinion index; Analysis of tax audit results; Expert knowledge, experienced tax auditors; Analyze the tax return data including the taxpayers' financial statements; Third Party Information (eg, bank); Other public information, especially information on the internet; Data on average indices; ...Statistical analysis is often used to examine taxpayer data and to find correlations between data and incompliance. It generally involves the use of the results of a pre-tax audit, which is then analyzed in conjunction with the data of the taxpayer. The OECD (2004) presents all stages of the risk management process that has been specifically guided by the Member States' tax departments, including the broad assessment of taxpayers, identification risk, risk assessment, compliance behavior analysis, identification of treatment options, application of measures and evaluation of achieved results. The OECD (2004) also proposes a detailed model for risk identification, which states that risk assessment criteria are one of the factors that shape the success of the model. In 2009, the OECD continues to provide guidance through a detailed report in the "Tax forum: Tax compliance management for large enterprise groups". In particular, the indicators for risk assessment include: (1) major changes in financial status or tax incurred over previous years/peers; (2) changes in business performance and uncollectible taxes; (3) consecutive; with a small amount of tax payable or not to be paid; (4) weakness in compliance with tax procedures; tax results are not suitable for tax law purposes; (5) revenue increases but tax arises ... (OECD 2009). The European Union Customs (EC 2006, 2010) describes compliance risk management as a systematic process in which the tax administration selectively and deliberately coordination can be able to stimulate compliance and prevent non-compliance based on an understanding of the behavior of taxpayers along with available resources. Increasing the effectiveness of compliance risk management is critical in the face of increasing tax risks due to complexity and innovation in the business structure, large numbers of taxpayers, the new financial products, the development of e-commerce. Then, the EC (2006) has detailed understanding of taxpayers' attitudes and behavior in compliance with treatment planning that incorporates a variety of approaches that influence each level of compliance. to form a compliant pyramid model. 


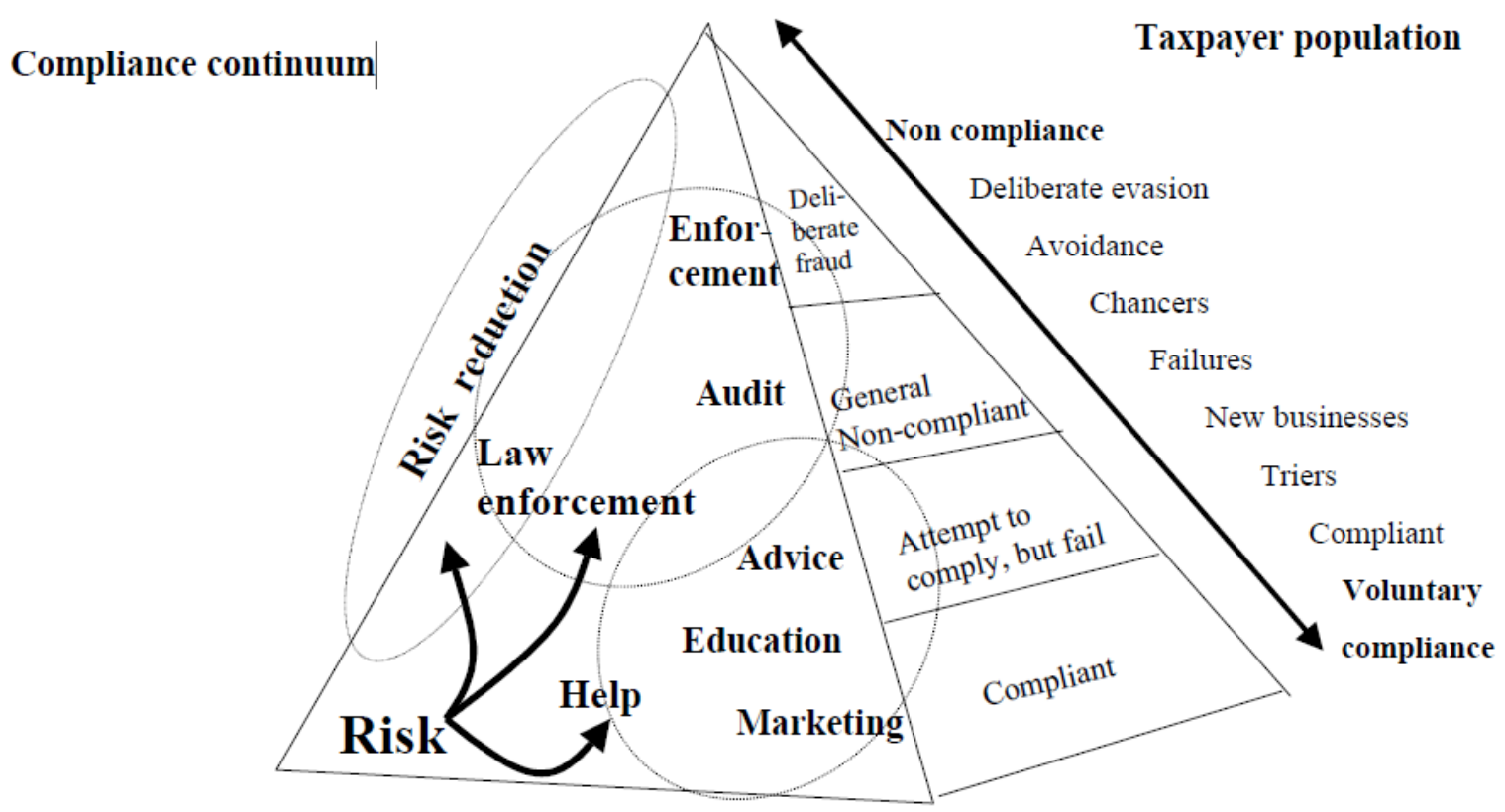

Figure 2. The compliance spectrum

Source: European commission-EC (2010).

The right side of the model reflects different taxpayers' attitudes toward compliance, from "readiness to comply", to "determination not to comply". In this model, taxpayer compliance will be assessed through a system of criteria to classify them into four levels of compliance from voluntary compliance to incompliance. The tax administration will take measures to influence taxpayers corresponding to each level of compliance, which applied singly but may also incorporate several measures for each level of compliance prime. Two rounds of intersecting measures are cut into each level of compliance to illustrate a combination of measures for different levels of compliance. The ultimate aim is to make the taxpayers move to the bottom of the tower in the "readiness". The main contents of the risk management process are presented at a basic level by the EC (2010) to open hints for use in each tax administration context. In particular, the EC (2010) introduced the experience of applying risk management in tax administration and tax audits in over 20 countries around the world with thorough descriptions of how they apply, the results achieved and the key issues arising from those practical cases. For example, value added tax analysis for each tax code in Italy; national database of risks in the Netherlands; estimation of the tax gap in Sweden; fighting underground economy has an impact on taxation in Denmark; ... The risk management guidelines for tax departments have been very clear on the risk management process in many countries. Although there is no uniform set of criteria for use in the region because each country's tax system has different characteristics, the European Commission (EC) recommends that the criteria applied must be specifically and measurable (for example, a sales growth rate of less than $\mathrm{x} \%$ or a difference in sales $\mathrm{x} \%$ in comparison with other similar taxpayers) and it is important to develop and report software, databases as the basis for the analysis and evaluation of those criteria. The Australian Taxation Office has presented a very practical content that is a description of the behavior and evidence for the behavior.

Table 1. Behavioural Characteristics indicated by Compliance Postures of Taxpayers

\begin{tabular}{|c|c|}
\hline Behavioural characteristics & Evidenced by \\
\hline $\begin{array}{l}\text { Willing to comply and take all reasonable steps to } \\
\text { do so These taxpayers give every indication of } \\
\text { consistent compliance across all compliance } \\
\text { obligations. }\end{array}$ & $\begin{array}{ll}- & \text { Lodgement on time } \\
- & \text { Payment on time } \\
- & \text { Correct completion of required labels in tax } \\
\text { returns or schedules }\end{array}$ \\
\hline
\end{tabular}




\begin{tabular}{|c|c|}
\hline & 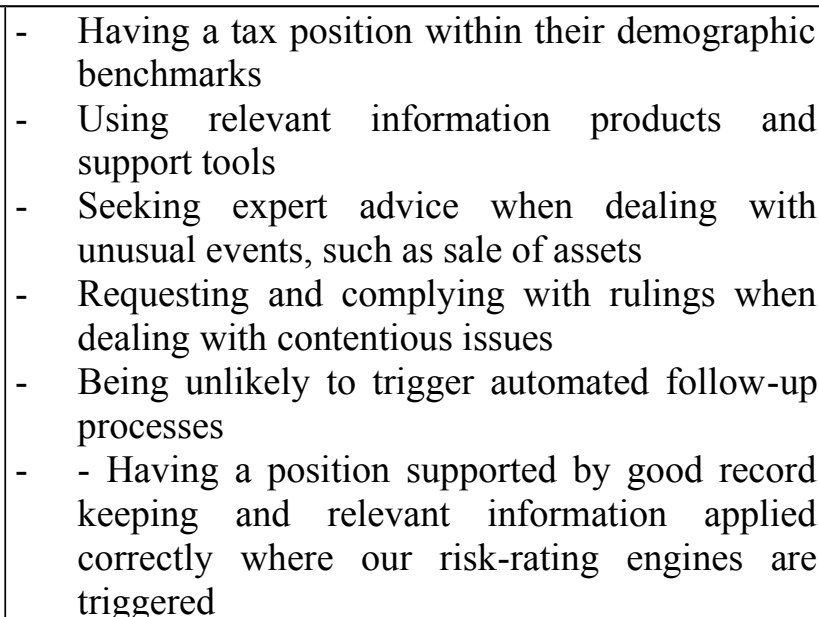 \\
\hline $\begin{array}{l}\text { Willing to comply but sometimes fail These } \\
\text { taxpayers may not be aware they have a specific } \\
\text { tax obligation, or just need assistance to comply } \\
\text { with them. } \\
\text { - Taxpayers may take their guidance from peers or } \\
\text { acquaintances. However, such advice may not } \\
\text { always be correct. } \\
\text { - In attempting to legally minimise their tax } \\
\text { obligations, taxpayers may adopt a position which } \\
\text { is contrary to our view of the law. This may give } \\
\text { rise to a dispute. }\end{array}$ & $\begin{array}{l}\text { - May occasionally lodge or pay late } \\
\text { - May include information at the wrong the } \\
\text { label of a tax return or schedule } \\
\text { - May incorrectly calculate amounts } \\
\text { - May not use relevant information and } \\
\text { support tools } \\
\text { - May use relevant information and support } \\
\text { tools but apply them incorrectly } \\
\text { - May not seek advice on unusual transactions } \\
\text { - May take a 'best guess' on more complex } \\
\text { law issues or do what they believe others are } \\
\text { doing } \\
\text { - May sometimes trigger automated follow-up } \\
\text { processes } \\
\text { - Will respond and put appropriate corrective } \\
\text { action into place when automated follow-up } \\
\text { processes are triggered } \\
\text { - When an alert is triggered in a risk rating } \\
\text { engine, further examination reveals there are } \\
\text { some issues which require further examination } \\
\text { to establish correct calculations or application } \\
\text { of the law }\end{array}$ \\
\hline $\begin{array}{l}\text { Taxpayer behaviour indicates a preparedness to } \\
\text { test the boundaries of the law in order to minimise } \\
\text { tax obligations. }\end{array}$ & $\begin{array}{l}\text { - Generally lodge and pay in an acceptable } \\
\text { timeframe but are prepared to take some risks in } \\
\text { reporting } \\
\text { - Taxpayers, and/or their advisers, may } \\
\text { consider they have a 'reasonably arguable } \\
\text { position' and may or may not seek a Tax Office } \\
\text { ruling on the issue } \\
\text { - More likely to be detected by risk-rating } \\
\text { engines and refund mechanisms } \\
\text { - Structuring of taxpayer business } \\
\text { arrangements and entities may be driven by tax } \\
\text { advantages rather than business needs } \\
\text { - Tax performance outside } \\
\text { benchmarks industry } \\
\text { - History of poor compliance, likely repeating } \\
\text { the same behaviour every year } \\
\text { - Taxpayers may seek advisers known for } \\
\text { 'pushing the boundaries' } \\
\text { - Non compliant tax agent/advisers may be }\end{array}$ \\
\hline
\end{tabular}




\begin{tabular}{|c|c|}
\hline & $\begin{array}{l}\text { detected through comparative taxpayer client } \\
\text { base performance with other agents/advisers }\end{array}$ \\
\hline $\begin{array}{l}\text { Taxpayer behaviour indicates deliberate intention } \\
\text { to evade tax obligations and, perhaps, defraud the } \\
\text { system. }\end{array}$ & $\begin{array}{l}\text { - May not be registered in the system but } \\
\text { detected through third party information } \\
\text { - May be a continual or habitual late lodger } \\
\text { and payer } \\
\text { - May deliberately omit income and/or over- } \\
\text { claim expenses } \\
\text { - May develop fictitious identities and entities } \\
\text { - May have a history of poor compliance with } \\
\text { issues primarily related to incorrect reporting } \\
\text { - Taxpayer/adviser fails to provide information } \\
\text { when requested the } \\
\text { - Taxpayer/adviser challenges } \\
\text { Commissioner's powers and prolongs the } \\
\text { processes } \\
\text { - Taxpayer may have had previous sanctions } \\
\text { such as prosecution } \\
\text { - Taxpayer/adviser may have developed } \\
\text { complex structures and transactions to hide the } \\
\text { taxation consequences }\end{array}$ \\
\hline
\end{tabular}

Source: Australian Taxation Office-ATO (2009).

ATO (2009) describes key principles and models that guide how to develop strategies while providing a number of case studies of strategies that are relevant to: Issues related to tax compliance in the use of labor; Issues related to tax compliance in cash economy; Issues related to tax compliance for transfer pricing... The research was conducted through experts, using tax audit method or tax task force, etc., to assess impacts, lesson learned, and strategic adjustment.

\subsection{2}

In the country studies

In recent years, there have been a lot of scientific researches on issues related to tax administration in Vietnam. However, there is only one doctoral dissertation which has direct and in-depth study of risk management in tax inspection. The results of these scientific studies have added insights into the field of tax administration in the context of Vietnam. Specific studies are as follows:

$\mathrm{PhD}$ studies related to tax administration, which mentioned the application of risk management in tax administration. However, they are not a critical objective, so these studies do not delve into the specific problems of compliance risk management. We could mention doctoral theses: "Renovation of tax administration in the context of economic integration in Vietnam" by Le Duy Thanh (2007); "Improving tax collection management of the State to enhance corporate tax compliance (case study of Hanoi)" by Nguyen Thi Le Thuy (2009); Hoang Thi Thuy Ngoc (2010) with the artical "Tax Management for Vietnamese Private Sector Enterprises in the Context of International Economic Integration". The doctoral dissertation by Nguyen Xuan Thanh (2013), Academy of Finance, Hanoi, research on tax inspections should include "Improving the efficiency of taxpayer inspection in Vietnam at present". In his research, the author presents vertical analysis methods, horizontal analysis, rate analysis for financial statements, tax returns, taxpayer compliance history in risk assessment when planning tax inspections. The author makes a completely accurate assessment of the effectiveness of tax inspections, which is highly dependent on identifying the right auditor at the initial planning stage. Then, the author has proposed a number of criteria for risk assessment, proposing the establishment of an automated risk scoring system to apply appropriate risk management measures. However, the thesis has not investigated directly the issues related to risk management, solutions to risks during the inspection process, especially 
for the abnormal signs that the system criteria for assessing risks when selecting nonidentifying audiences. This is the gap in the study of the thesis that should be further studied. Tran Huy Truong (2015) "Risk Management in Tax Inspectorate for Enterprises in Vietnam" is the in-depth study at the first doctoral level in Vietnam, which is directly application for risk management in tax inspections. The author explains the meaning of the risk assessment criteria in the tax audit. The dissertation has introduced the criteria for assessing the application of risk management to tax inspection and analyzes the factors that affect the risk management in tax inspection. The thesis has systematically assessed the current status of risk management in tax inspection according to risk indicators for the period from 2009 to 2014 in Vietnam. However, due to the study during the period 2009-2014, the period for notifying information about the bank payment transactions with abnormal markings related to tax compliance was not detected in the whole of the thesis. refers to the review and assessment of the risk of compliance with taxes on unusual bank payment transactions.

Research topic at the Academy (Finance Academy, Hanoi) by Le Xuan Truong and Nguyen Thi Lien (2013) on "Completing the system of indicators used in tax inspection": theoretical issues on tax inspection and the system of norms used in tax audits are systematized from concepts to contents and methods in tax inspection, classification of indicators used in tax inspections. Through the two sets of indicators (groups of indicators applicable to taxpayers' inspection activities and groups of indicators for assessment of tax inspection activities), the subject has assessed the actual situation of tax inspection activities of Vietnam Tax Agency. In conclusion, the results obtained concurrently show the limitations of the indicators currently applied in tax inspection activities in Vietnam.

"Regulatory Compliance Management: administrion and the advancement of tax compliance" by the Organization for Economic Cooperation and Development (OECD, 2004) can be seen as a sourcebook for many research and risk administration applications in the tax area from the perspective of the tax administration. The specific characteristics of compliance risk management from the OECD tax administration approach are very significant and condensed with the compliance triangulation model in the context of the interaction between the mechanics tax administration officers and tax payers. This model has been successfully applied in tax administration by the Australian Taxation Agency (ATO). In particular, from the taxpayers behaviour in registering, declaring and paying taxes, the ATO has uncovered credible evidence that can be assessed according to levels of tax compliance. However, all risk management compliance guidelines do not provide any set of risk assessment criteria for national tax department, as recommended by the OECD that tax administration scene is not the same. Although the OECD, the EC and the ATO are not guided by a set of criteria for risk assessment, they provide guidance on how to develop a set of criteria, as well as the introduction of practical experience in many countries.

4.

\section{Conclusion}

The paper presents many previous studies on tax compliance / incompliance briefly and systematically, and closely analyzing the documents of OECD, EC, and ATO on risk compliance management, so that it will be applicable for this study, which is built on Vietnam context. Thus, this study has determined the tax compliance risk for bank payment transactions in the tax administration context in Vietnam since 2014. This kind of behavior is intentionally disobedient to the law, which results in dishonest tax report and inaccuracy in the tax amount needed to be submitted. Therefore, the study focusing on tax compliance is necessary and useful, not only for science but also for tax department in countries with the same tax administration context as Vietnam, where database related to taxpayer's business activities between banks and tax department is insufficient in many aspects. Up to now, the writer has not discovered any study that is identical to this one. 


\section{References}

Adam F, Sheffrin SM. 2002. Complexity and Compliance: An Empirical Investigation. National Tax Journal LV(1): 75-88

Allingham M, Sandmo A. 1972. Income tax evasion: a theoretical analysis. Journal of Public Economics. 1: 323-338

Alm J. 1991. A perspective on the experimental analysis of taxpayer reporting, The Accounting Review. 66(3): 577 - 593

Andreoni J, Erard B, Feinstein J. 1998. Tax Compliance. Journal of Economic Literature. 36: 818-860.

ATP: Australian Taxation Office. 2009. Developing effective compliance strategies.

Beck P. J., Davis J. S., and Jung W., 1991 Experimental Evidence on Taxpayer Reporting Under Uncertainty. The Accounting Review, 66(3), 535-558.

Carnes GA, Englebrecht TD. 1995. An Investigation of the Effect of Detection Risk Perceptions, Penalty Sanctions, and Income Visibility on Tax Compliance. The Journal of the American Taxation Association. 17(1): 26-41.

Christian C. W., and Gupta S., 1992 New Evidence on Secondary Evasion. The Journal of the American Taxation Association, 72 - 93.

Clotfelter CT. 1983. Tax Evasion and Tax Rates: An Analysis of Individual Returns. Review of Economics and Statistics. 65(3): 363-373.

Cuccia AD. 1994. The Effects Of Increased Sanctions On Paid Tax Preparers: Integrating Economic And Psychological Factors. The Journal of the American Taxation Association. 16(1): 41-66.

Dublin JA, Wilde LL. 1988. An Empirical Analysis of Federal Income Tax Auditing and Compliance. National Tax Journal. 41(1): 61-74.

EC: European commission. 2006. Risk management guide for tax administrations. Directorate General Taxation and Customs Union.

EC: European commission. 2010. Compliance Risk Management Guide. Directorate General Taxation and Customs Union.

Feinstein JS. 1991. An Econometric Analysis of Income Tax Evasion and Its Detection. Rand 22(1): 14-35.

Forest A, Sheffrin SM. 2002. Complexity and Compliance: An Empirical Investigation. National Tax Journal. LV: 75 -88.

Frey B. S., and Feld L. P., 2002 Deterrence and Morale in Taxation. University of Zurich, Switzerland. International Journal of Business and Social Science Vol. 2 No. 7; [Special Issue -April 2011]

Gupta AD. 2002. The Economic Theory of Tax Compliance with special reference to Tax Compliance Costs. Proceedings at National Institute of Public Finance And Policy. India.

Hoàng Thị Thúy Ngọc. 2010. Quản lý thuế đối với các doanh nghiệp thuộc khu vực kinh tế tư nhân Việt Nam trong bối cảnh hội nhập kinh tế quốc tế. Luận án tiến sĩ Kinh tế, Viện Khoa học Xã hội Việt Nam - Học viện Khoa học Xã hội, TP. Hà Nội, Việt Nam.

Jackson BR, Milliron VC. 1986. Tax compliance research: Findings, problems, and prospects. Journal of Accounting Literature. 5: 125-165

James S, Alley C. 2004. Tax Compliance, self-assessment and tax administration. Journal of Finance and Management in Public Services. 2(2): 27-42.

Joulfanian D, Rider M. 1998. Tax Evasion By Small Business: Office Tax Analysis (OTA) Workingpaper. USA: Georgia State University.

Kirchler E. 2007. The economic psychology of tax behavior. Cambridge: Cambridge University Press.

Lederman L. 2003. The Interplay Between Norms and Enforcement in Tax Compliance", Law 
and Economics. Working Paper. USA: George Mason University.

Lê Duy Thành. 2006. Đổi mới quản lý thuế trong điều kiện hội nhập kinh tế ở Việt Nam. Luận án tiến sĩ kinh tế, Học viện Tài chính, TP. Hà Nội, Việt Nam.

Lê Xuân Trường, Nguyễn Thị Liên. 2013. Hoàn thiện hệ thống chỉ tiêu sử dụng trong thanh tra thuế. Đề tài nghiên cứu khoa học cấp Học viện, Học viện Tài chính, Hà Nội, Việt Nam.

Massimo B. 1993. A Fairness Approach to Income Tax Evasion. Journal of Public Economics. 52(3): 345-362

Milliron VC, Toy GR. 1988. Tax Compliance: An Investigation of Key Features. The Journal of the American Taxation Association. 84-103.

Nguyễn Thị Lệ Thúy. 2009. Hoàn thiện quản lý thu thuế của Nhà nước nhằm tăng cường sự tuân thủ thuế của doanh nghiệp (nghiên cứu tình huống của Hà Nội). Luận án tiến sĩ Kinh tế, Trường Đại học Kinh tế Quốc dân, TP. Hà Nội, Việt Nam.

Nguyễn Xuân Thành. 2013. Nâng cao hiệu quả thanh tra người nộp thuế ở Việt Nam giai đoạn hiện nay. Luận án tiến sĩ Kinh tế, Học viện Tài chính, TP. Hà Nội, Việt Nam

OECD: Organisation for Economic Co-operation and Development. 2001. The OECD'S Project on harmful Tax practices: The 2001 progress report. Centre for Tax Policy and Administration.

OECD: Organisation for Economic Co-operation and Development. 2004 Compliance Risk Management: Managing and Improving Tax Compliance. Centre for Tax Policy and Administration.

OECD: Organisation for Economic Co-operation and Development. 2009 General Adminstrative Principles: Corporate governance and tax risk management. Centre for Tax Policy and Administration.

Porcano MT. 1998. Correlates of tax evasion. Journal of economic psychology. 9(1): 47-67.

Richard MB. 2015. Improving Tax Administration in Developing Countries. Journal of Tax Administration. 1(1): 23-45.

Roberts ML. 1994. An Experimental Approach to Changing Taxpayers; Attitudes Toward Fairness and Compliance via Television. The Journal of the American Taxation Association. 16(1): 67-86.

Schuetze HJ. 2002. Profiles of Tax Noncompliance Among the Self-Employed in Canada 19691992, Workingpaper. Canada: University of Victoria.

Singh V. 2003a. Tax Compliance And Ethical Decision-Making: A Malaysian Perspective. 1st edn, Malaysia: Pearson Malaysia Sdn. Bhd.

Singh V., 2003b. Malaysian Tax Adminitration, 6th ed, Kuala Lumpur: Longman.

Song YD, Yarbrough TE. 1978. Tax ethics and taxpayer attitudes: A survey. Public Administration Review. 38(5): 442 - 452.

Sour DL. 2001. An Analysis of Tax Compliance For The Mexican Case: Experimental Evidence. [Dissertation]. USA: University of Illinois.

Spicer MW, Becker LA. 1980. Fiscal Inequity and Tax Evasion: An Experimental Approach. National Tax Journal. 33: 171-175.

Torgler B. 2007. Tax Compliance and Tax Morale: A Theoretical and Empirical Analysis. Cheltenham. UK: Edward Elgar.

Trần Huy Trường. 2015. Quản lý rủi ro trong hoạt động thanh tra thuế đối với doanh nghiệp ở Việt Nam. Luận án tiến sĩ Kinh tế, Học viện Tài chính, TP. Hà Nội, Việt Nam.

Trivedi VU, M Shehata, Stuart M. 2004. Attitudes, incentives, and tax compliance. Hamilton: McMaster University.

White RA, Harrison DP, Harrel A. 1993. The Impact of Income Tax Withholding on Taxpayer Compliance: Further Empirical Evidence. The Journal of the American Taxation Association. 63-78.

Witte A, Woodbury DF. 1985. What we know about the factors affecting compliance with the tax law? In P.Sawicki (ed.), Income tax compliance: A report of The ABA Section of 
Taxation Invitational Conference on Income Tax Compliance. Chicago: American Barr Association.

Young JC. 1994. Factors Associated With Noncompliance: Evidence from Michigan Tax Amnesty Program. The Journal of the American Taxation Association. 16(2): 82-105. 